\title{
«Я КАЖДЫЙ ДЕНЬ ЖДУ ВЫСТРЕЛА В СЕБЯ...» (Орудия смерти в произведениях В. Хлебникова)
}

\author{
Вячеслав Куприянов 1
}

\begin{abstract}
The poet Velimir Khlébnikov is known for his pacifist stance in the context of the avant-garde movements in Russia. This article focuses on analyzing the occurrence of the war theme in Khlebnikov's work, by looking at the semantic aspects involved in the author's choices, such as references to different weapons and wars throughout history.
\end{abstract}

Keywords: Velimir Khlébnikov; Russian literature; Russian poetry

Resumo: O poeta Velimir Khlébnikov é conhecido por sua postura pacifista no contexto dos movimentos de vanguarda na Rússia. Este trabalho busca analisar a manifestação da temática das guerras na obra de Khlébnikov, a partir da observação de aspectos semânticos envolvidos nas escolhas do autor, como as referências a diversas armas e às diferentes guerras no decorrer da história.

Palavras-chave: Velimir Khlébnikov; Literatura russa; Poesia Russa

«Я воин; время - винтарь», - провозглашает Зангези, главный герой одноимённой сверхповести Хлебникова и alter-ego самого поэта. По сути, устами своего героя «о времени и о себе» рассказывает сам Хлебников, неизменный участник или свидетель всех «горячих точек» своей эпохи: первой мировой войны, февральской революции, октябрьского переворота, гилянского похода. «Я каждый день жду выстрела в себя» ${ }^{1},-$ скажет поэт. Война - одна из ключевых тем всего его творчества, чей эпический размах позволяет отразить её не только в масштабах России, но и за её пределами: «Вам» (Кавказская война, 1859), «Тиран без Тэ» (Гилянские события, 1921), «Смерть Паливоды» (Запорожская Сечь, XVIXVII вв.), «Управда» (Византия, эпоха императора Юстиниана, 527-65 гг.) и т.д.

Отсюда - многочисленные упоминания орудий смерти, от каменного топора до будетлянского пророчества: «атомная бомба - разорвана» ${ }^{2}$ : кинжал (15 упоминаний), копьё( 82), меч(163), нож(94), шашка(47), лук(29), стрела(39) и т.д.

Интересна связь «лука» (или «стрелы») с образом оленя в ряде произведений поэта. Зачастую его олень - трагическое существо. Он или петляет между жизнью и смертью («Трущобы»), или томится в неволе («Зверинец»), или становится жертвой копья, пищали с кремнями, но чаще всего - стрелы:

\footnotetext{
${ }^{1}$ Escritor Russo, vencedor de diversos prêmios literários.
} 
И чаще лука кольханье,

Оленю нету, нет спасенья.

$$
\text { «рущцобы». }
$$

Пусть здравствует, трепет неся, тетива,

Где скачка за лосем ещеё не наскучила...

$$
\text { «Признание». }
$$

Олень, олень, зачем он тяжко

В рогах глагол любви несёт?

Стрель вспорхнула медь на ляжку,

И не ошибочен расчёт.

$$
\text { «рущщобы». }
$$

Потом хватает лук и стрельь

И мимо просьб, молитв, молений

Идёт охотник гордьій, смельий

К чете пасущихся оленей.

«Шаман и Венера».

Сделай так, чтоб бег дробя,

Пали с стрелами олени...

$$
\text { «И } и \text { Э». }
$$

Здесь не исключена реминисценция «Книги притчей Соломоновых», где, в притче о блудной жене, завлекающей в свой дом чужого мужа, говорится: «Тотчас он пошёл за нею (...) как олень - на выстрел, доколе стрела не пронзит печени его» ${ }^{3}$.

Возможно и то, что Хлебников знал знаменитую индийскую Оленью Джатыку (или «Притчу о благородном олене»), где в центре медальона изображён олень - реинкарнация Будды, в которого целится из лука охотник ${ }^{4}$.

С параллелью «олень - копьё» у поэта связан следующий фрагмент:

Вечер. Тени.

Сени. Лени.

Мы сидели, вечер пья.

В каждом глазе - бег оленя,

В каждом взоре - лёт копья. ${ }^{5}$ 
Автор вносит в этот фрагмент мужское и женское начала. В вечерней тени расслаблено отдыхают юноша и девушка («вечер пья»), увлечённые любовной игрой, поединком глаз: дева убегает, не давая себя поймать («В каждом глазе - бег оленя»), а юноша преследует, настигает («В каждом взоре - лёт копья»). Налицо сложный образ: «Копьё» взора настигает «оленя» гла́за. В данном случае нетрафаретный образ может послужить аналогом пресловутой «стрелы Амура».

Кистень (по Далю) - «ручное дорожное оружие: ядро, гиря, рогулька на ремне» ${ }^{6}$ Его многократное упоминание ассоциируется у Хлебникова прежде всего с «Разинским кистенём» ${ }^{7}$. С «разбойным взмахом кистеня» ${ }^{8}$ Велимир связывает своё творчество и свою жизнь - «мои походы» ${ }^{9}$.

Я слова бурного разбойник,

Мои слова - кистень на Волге! ${ }^{10}$

В этих строчках - хлебниковская натура волжанина, бунтаря, Разина от поэзии:

Я прихожу к вам тенью Разина

На зов [широкого] весла.

От реснии упала тень,

А в руке висит кистень. ${ }^{11}$

Есть свидетельство, что он был знаком с кистенём и в прямом смысле: «Я имел старый медный кистень с круглыми шишками», - сообщает поэт в прозаической миниатюре «Это было старое озеро...», приблизительно датируемой 1911 годом. Именно в сентябре 1911 года он гостил в Астрахани у своего крёстного отца Бориса Лаврентьевича Хлебникова. В честь приезда крестника тот подарил ему золотые часы. «Витя ими очень забавляется: "часики", - говорит он и проектирует на другой конец цепи привесить кистень» ${ }^{12}$, - свидетельствует младший брат поэта Александр Хлебников. Очевидно, в случае нападения, Велимир готовился защищать золотые часы с помощью кистеня. Но утратил их в результате спора с Борисом: «Честны или нечестны астраханцы?» Уверенный в честности своих земляков, поэт вынес часы на улицу и повесил на столб. Какое-то время они висели, потом исчезли. Но через несколько дней часы отыскались: их кто-то «узнал». И Хлебникову их вернули ${ }^{13}$.

Поэт неоднократно соотносит орудия смерти с человеческой плотью:

Хребет утончился носа,

Острый, как ножик, ${ }^{14}$ 
- о детях голодающего Поволжья.

...сжатая обойма - $у$ жа. ${ }^{15}$

Глаза человека - секира. ${ }^{16}$

Челюсти - ножи, ${ }^{17}$

Вот Лена с глазами расстрела... ${ }^{18}$

По семейному преданию, Велимир никогда не расставался с репродукцией «Расстрел рабочих на Ленских приисках 1912» ${ }^{19}$.

Рука бомб бей... ${ }^{20}-$

призыв к свержению английских колонизаторов в Индии. В словосочетании «бомб бей» прослеживается анаграмма с названием индийского города Бомбея.

Порою разные виды оружия обозначены у Хлебникова иносказательно:

Bетер чугунных осn ${ }^{21}$

Чугунные выскочки ${ }^{22}$

Пастбище смертей с рукоятью ${ }^{23}$

Над городом взошёл заморский меч.

Косой, кривой... ${ }^{24}$

С орудиями смерти у Хлебникова связано множество неологизмов. Приведём некоторые из них.

Свинеи согласно ненавидим -

Сию железную летаву. ${ }^{25}$

Летава - это «летящая лава» свинца ${ }^{26}$. Но в статье «Образчик словоновшеств в языке» мы узнаём, что этот неологизм может означать и воздушную эскадру: «Две летавы встретились, готовые к бою» ${ }^{27}$. Неологизм «летва» («Жужжит свинцовая летва» ${ }^{28}$ ) означает снаряды и пули.

Железавут играет в бубен,

Надел на пальиы шумы пушек. ${ }^{29}$

Обратимся к блистательному комментарию В. Маяковского: «...Мне ничего не говорит слово «жестокость», а «железавут» - да. Потому что последнее звучит для меня такой какофонией, какой я себе представляю войну. В нём спаяны и лязг железа, и слышишь, как кого-то «зовут», и видишь, как этот позванный «лез» кудато...» ${ }^{30}$ 
Хлебников здесь применил приём «живописания звуком», о котором сообщал В.Каменскому в письме от 8 августа 1909 года. Примерно тогда же написана <«Война - Смерть»> 31

На небе бледном виден ужасчук

В мечавом и величавом на челе венце.. ${ }^{32}$

«Ужасчук», символ торжествующей смерти, - замечает исследователь Рональд Вроон, - носит венец из скрещённых мечей вместо тернового венца; у него бескровное лицо Бледного Всадника, и зовут его Война» ${ }^{33}$.

В стихотворении «На море» поэт рисует междоусобицу гражданской войны в Советской России, чреватую тем, что она - не только поединок белых и красных, но и отцов и детей:

И вот сыновеет выстрел ${ }^{34}$

- выстрел отнимает у родителей сына.

Аналогично:

Выстрел отиел. Могиль отиели. ${ }^{35}$

- выстрел забирает чьего-то отца.

Сынонож

в материнскую рожь! ${ }^{36}$

«Сынонож» - это серп Смерти, скосивший молодые жизни.

Перекличка со строчкой:

Tы, женщиина в белом, косящуая стебли ${ }^{37}$

и образом «человеческой ржи» ${ }^{38}$ в «Уструге Разина».

В стихотворении «Ззыз - - - жжа!» задействованы элементы звукописи и «звёздного языка». В нём - отклик поэта на крестьянские волнения в Тамбовской губернии, на так называемый «антоновский мятеж» (август 1920 - осень 1921), когда против мирного населения было применено отравляющее оружие.

Над этим селом опала.

Сегодня два снаряда

Мёртвого яда

В него упало. ${ }^{39}$

В строчках

Ззыз---жжа!

Паma nanm ma!

звуки «з» и «ж» имитируют свистящий полёт снаряда (Сp. «И вдруг же завизжало» ${ }^{40}$ ), а звуки «п» и «т»- его разрыв. Со звуком «п» Хлебников связывал 
«пушку, порох (...), пулю», которые «рассеивают прежде собранное вещество» ${ }^{41}$. С трагической концовкой стихотворения:

А воздух сладкий, как одиннадияать,

Стал ядовитым, как двадцать семь.

Под простынёю смерти

Заснуло село.

- поэт связал свою «числопись». Числу «11» он отводил особую роль. «11 - ворота в храм чисел (...). 11 есть свободный пропуск между небом и землей, туда и обратно» ${ }^{42}$

Число же «27» в стихотворении названо «ядовитым». Почему? Не потому ли, что $27=3^{3}$ (напомним, что «три», по Хлебникову, «злое число»). Или потому, что «27 июня 1850 года Баб был растре<лян>»? ${ }^{43}$ Баб (Али-Мухамед; 1820-1850) основатель секты бабидов - возглавил народное движение против приверженцев шариата и правительства шаха, по приказу которого впоследствии был расстрелян в Тебризе. Та же участь постигла и А.С. Антонова, поднявшего крестьянский мятеж на Тамбовщине.

С числом «27» связана и запись Хлебникова о внуке Юлия Цезаря: «27 января 27 года до Р. Х. принял звание Августа» ${ }^{44}$. Император Август установил жестокую военную диктатуру, в частности, направленную на подавление сопротивления рабов. А кем, как не рабами XX века, были тамбовские крестьяне, задавленные продразвёрсткой и доведённые до мятежа?

В статье «О футуризме» А.М. Горький писал: «...искусство должно быть вынесено на улицу, в народ, толпу, и это они делают» ${ }^{45}$. Прямое подтверждение горьковских слов - «Голоса и песни улицы» («Настоящее»), где говорят и поют не только люди, но и само оружие: «языком гремучих шашек», «железным голосом секиры», «первою чугунною обедней» и т.д.

Героиня поэмы «Настоящее» - Прачка - находит единственно подходящие ножны для «красавца-ножа»:

Он красавец, длинный нож,

В сердие барина хорош. ${ }^{46}$

Можно утверждать, что главным действующим лицом поэмы является не только Прачка, но и её «желанный жених»- Нож, упомянутый в тексте 25 раз. Попутно заметим, что если в поздних творениях Хлебникова ключевым орудием смерти является нож, то в ранних произведениях, наряду с луком и копьём, 
доминирует меч. Только в «Девьем боге» он упоминается 33 раза. В строчке стихотворения «Кубок печенежский»

Мㅜ забыли для м⿻ча

заложен приём внутреннего склонения слов, сформулированный Хлебниковым в статье «Учитель и ученик»: Бык - тот, кто нападает. Бок - куда направлен удар, и т.д.

Достаточно поменять «е»на «я» - и меч - орудие войны - превращается в мяч - символ игры, мира. Хлебников это многократно варьирует:

Ветер - пение

Кого и о чём?

Нетерпение

Мечча стать м⿻чом. ${ }^{47}$

Война и мечч, вы часто только м⿻ч

Лаптою занятых морей... 48

и т.д.

Великий миротворец, Хлебников мечтал о пришествии «Ладомира»на всей планете, сбросившей иго кровавых боен и усвоившей «уроки другой войны»:

Битвами запахов бились изветь,

Летели душистые пули. ${ }^{49}$

«О, в этой битве ияветов и я умереть готов! » ${ }^{50}$, - восклицает поэт. В войнах он предлагал пользоваться «сонными пулями» ${ }^{51}$, а вместо казней ввести «теневой расстрел» 52 . Такова была его чисто человеческая реакция на массовые расстрелы в Астрахани, Харькове, Баку.

Вместо массовых расстрелов поэт призывает устраивать массовые зрелища: «живопись пальбой»: «Снарядами разночветного дыма стреляли в разные точки неба. Например, глаза - вспьшкой синего дымма, губы - выстрелом алого дыма, волосы-серебряного» ${ }^{53}$.

Поразительно, но и спустя десять лет в сознании Велимира не умерло его «Бобэоби» <1908>, которое сам он объяснял следующим образом: «Б ярко красный цвет, а потому губы бобэоби, вээоми - синий, и потому глаза синие» ${ }^{54}$.

Хлебников мечтал примирить оружие и природу, смерть и живые ростки жизни:

Это синие гусары

На заснувшие ножи

Золотые лили чары 
Полевых колосьев ржи. ${ }^{55}$

Стихла вражда - и ножи заснули, убаюканные «золотыми чарами» колосьев.

«В каждой винтовке - ветка черёмухи» ${ }^{56}$, - ещё один образ стихшей войны и

наступившего мира. Хлебников решительно призывал покончить с войной, мечтая

о том, чтобы «воин меч вонзил в землю и ему исповедовался» ${ }^{57}$.

${ }^{1}$ Хлебников, В. Собрание сочинений: в 6 т. / Под общ. ред. Р.В. Дуганова; сост., подгот. текста и примеч. Е.Р. Арензона, Р.В. Дуганова. М. : ИМЛИ РАН, «Наследие», 2000-2006. Т. 3. С. 193. Далее - СС, с указанием тома и страницы. Большинство цитат приводится по этому изданию.

2 Вяч. Вс. Иванов. Хлебников и наука // Пути в незнаемое. Писатели рассказывают о науке. Сборник двадцатый. М. : Советский писатель, 1986. С. 390.

${ }^{3}$ Книга притчей Соломоновых. Глава 8 // Новый завет. Минск: Библейская Лига, 2001. С. 132.

${ }^{4}$ Искусство Индии, III тыс. до н. э. - XVIII в. Исследованы материалы с сайта http://artclassic.edu.ru

${ }_{6}^{5}$ CC. T. 1. C. 134.

${ }^{6}$ Владимир Даль .Толковый словарь живого великорусского языка в 4-х томах. Москва.Государственное издательство иностранных и национальных словарей. 1956.Том 2.С. 111.

${ }^{7}$ CC. T. 3. C. 161.

${ }^{8}$ CC. T. 2. C. 321

${ }^{9}$ Там же.

${ }^{10}$ CC. T. 5. C. 351.

${ }^{11}$ CC. T. 3. C. 41.

${ }_{12}^{12}$ Хлебников А.В. Письма к родным. 1905-1916 гг. // Волга (Саратов), 1987. № 9. С. 148.

13 Мамаев А.А. Астрахань Велимира Хлебникова. Документальная повесть. - ГП «Издательскополиграфический комплекс "Волга"». Астрахань, 2007. С. 19.

${ }_{15}^{14}$ CC. T. 3. C. 319.

${ }^{15}$ CC. T. 2. C. 427.

${ }^{16}$ CC. T. 3. C. 230 .

${ }^{17}$ Там же. С. 217

${ }^{18}$ Там же. С. 375.

${ }^{19}$ Фонды Дома-музея Велимира Хлебникова.

${ }^{20}$ Hacker Andrea. Velimir Xlebnikov's Doski Sud'by. Text. Discourse. Vision. A dissertation submitted in partial satisfaction of the requirements for the degree of Doctor of Philisophy in Slavic Languages and Literatures. University of California. Los Angeles. 2002. P. 136.

${ }^{21}$ CC. T. 3. C. 240.

${ }^{22}$ Там же. С. 334.

${ }^{23}$ CC. T. 5. C. 257.

${ }^{24}$ CC. T. 3. C. 362.

${ }^{25}$ CC. T. 3. C. 49.

${ }^{26}$ Выражаю признательность И.В. Чудасову, обратившему на это моё внимание (A. M.)

${ }^{27}$ СС. Т. 6. Книга первая. С. 29.

${ }^{28}$ CC. T. 3. C. 51.

${ }^{29}$ Там же. С. 53.

${ }^{30}$ Маяковский В. Полное собрание сочинений: в 13 т. М., 1955-1961. Т. 1. С. 328.

31 Составители собрания сочинений Велимира Хлебникова в 6 т. датируют это стихотворение предположительно 1910 годом.

${ }^{32}$ CC. T. 3. C. 54.

${ }^{33}$ Vroon Ronand. Velimir Xlebnikov's shorter Poems. A Key to the Coinages. Ann Arbor, 1983. Р. 77. Цитируется в переводе на русский язык.

${ }^{34}$ CC. T. 2. C. 488.

${ }^{35}$ Там же. С. 486.

${ }^{36}$ Там же.

${ }^{37}$ CC. T. 3. C. 180.

${ }^{38}$ Там же. С. 357.

${ }^{39}$ CC. T. 2. C. 264.

${ }^{40}$ CC. T. 3. C. 334.

${ }^{41}$ CП. Т. V. C. 208.

42 Блокнот с выкладками для «Досок Судьбы»// Лённквист Барбара. Мироздание в слове. Поэтика

В. Хлебникова. СПб. : Академический проект, 1999. С. 22. 
${ }^{43}$ Евразийское пространство. Звук, слово, образ. М. : Языки славянской культуры, 2003. С. 288.

${ }^{44}$ Темы и вариации. Сборник статей и материалов к 50-летию Лазаря Флейшмана. Стэндфорд, 1994. С. 336.

${ }^{45}$ Горький М. О футуризме // Журнал журналов, 1915. № 1.

46 Здесь и далее подчёркнуто мною (А. М.)

${ }^{47}$ CC. T. 3. C. 191.

${ }^{48}$ Там же. С. 126.

${ }^{49}$ CC. T. 2. C. 185.

${ }^{50}$ CC. T. 4. C. 187.

${ }^{51}$ СС. Т. 6. Книга первая. С. 241.

52 Там же. С. 279.

${ }^{53}$ СС. Т. 6. Книга первая. С. 139.

${ }^{54}$ CП. T. V. C. 276.

${ }^{55}$ CC. T. 2. C. 100 .

${ }^{56}$ Там же. С. 101.

${ }^{57}$ Баран Х. О Хлебникове. Контексты, источники, мифы. М. : Российск. гос. гуманит. ун-т, 2002. С. 379. 